\title{
Analysis of the effect of store attributes to perceived relationship investment, perceived relationship quality, and attitudinal loyalty of Metro Department Store Customer in Surabaya
}

\author{
Seisy Elvira Palit ${ }^{\mathrm{a} *}$, Amelia $^{\mathrm{b}}$, Ronald $^{\mathrm{c}}$ \\ a seisypalit1@gmail.com \\ ${ }^{a}$ Master of Management Student at Pelita Harapan University, Surabaya 60234, Indonesia \\ ${ }^{b, c}$ The Lecturer of Master of Management at Pelita Harapan University, Surabaya 60234, Indonesia
}

\begin{abstract}
The growth of the retail business in Indonesia shows a significant number. In this case, requires retail companies to be able to meet customer needs and adjust customer desires so that the company must be able to detect what the market needs and desires of consumers. Therefore the presence of METRO Department Store is very influential in the development of the retail industry, especially in Surabaya. This research is intended to analyze the effect of the Store Attributes variable on Perceived Relationship Investment, Perceived Relationship Quality and Attitudinal Loyalty of METRO Department Store customers in Surabaya. The sample used in this study were men and women, aged 18-60 years who lived in the city of Surabaya, a total of 145 respondents who had visited and purchased at METRO Department Store, had used products purchased at METRO Department Store, were active members, and who know about post-purchase services at METRO Department Store. For processing and analyzing data in this study using SPSS 22 as a software to process data. These empirical findings indicate that the relationship between Post Transaction Service has an effect on Perceived Relationship Investment with a regression coefficient of 0.120, Direct Mail has an influence on Perceived Relationship Investment with a regression coefficient of 0.115, Interpersonal Communication has an influence on Perceived Relationship Investment with a regression coefficient of 0.138 , Preferential Treatment has an influence on Perceived Relationship Investment with a regression coefficient of 0.104, Store Atmosphere has an influence on Perceived Relationship Investment with a regression coefficient of 0.164 , Merchandise has an influence on Perceived Relationship Investment with a regression coefficient of 0.497, Perceived Relationship Investment has an influence on Perceived Relationship Quality with a coefficient regression of 0.658 , and Perceived Relationship Quality has an influence on Attitudinal Loyalty with coefficient regression of 0.505 .
\end{abstract}

Key Words: Post Transaction Service, Direct Mail, Interpersonal Communication, Preferential Treatment, Store Atmosphere, Merchandise, Perceived Relationship Investment, Perceived Relationship Quality, Attitudinal Loyalty

\section{Introduction}

The economic growth of a society will have an impact on increasing purchasing power and at the same time stimulating the market. The increase in people's purchasing power is usually triggered by higher income derived from the salary or income of a family or community group. This high purchasing power will directly or indirectly encourage the emergence of markets and shopping centers, as a means of carrying out transactions between sellers and buyers. The presence of modern shopping centers in big cities is an indicator of economic growth. (Soliha,2016) The growing development of the retail industry in Indonesia has made the competition among companies in the industry getting tougher. The retail business is a type of business that requires a large amount of capital, but the developments that occur in this business do not only depend on the availability of 

ventures that directly direct their marketing capabilities to satisfy end consumers based on the organization of selling goods and services as the core of distribution (Gilbert, 2014).

Retail is an important chain in the distribution process of goods and is the last link in a distribution process. Through retail, a product can meet directly with its users. The retail industry is defined here as an industry that sells products and services that have been added value to meet the needs of individuals, families, groups or end users. The products sold are mostly household needs (Utami, 2010). The retail business in Indonesia itself can be classified into two major groups, namely modern retail and traditional retail. Modern retail is basically an expansion from traditional retail. The modern retail paradigm is a view that emphasizes retail management using a modern approach where the concept of retailer management is emphasized from the point of view of meeting the needs of consumers who are the target market (ilmuritel.com, downloaded on May 20, 2020).

The retail business is generally divided into two categories, namely traditional retail and modern retail. Basically, modern retail is a retail format that stands along with the development of the economy. Modern retail is a format for selling places that evolved from traditional markets. Modern retail was already established in Indonesia in 1962 to be precise. However, this modern retail did not really develop until the 1990s, marked by the establishment of various shopping centers and the entry of a foreign retailer from Japan to Indonesia. In general, the modern retail format takes many forms, adjusted to the conditions in a region, both preferences and income levels. As time goes by and the times continue to change, this modern retail format is still developing from time to time. However, in general, the retail business format which is currently growing rapidly in Indonesia is divided into four major formats, namely hypermarkets, supermarkets, minimarkets or convenience stores, department stores, and specialty stores, where the main characteristic difference lies in the area of space and product variations. offered (elmodista.com downloaded on May 20, 2020).

The presence of modern retail offers convenient shopping activities, with various modern facilities such as escalators / escalators, spacious, comfortable and air-conditioned shopping rooms, as well as the availability of various necessities, so that visitors are comfortable and satisfied. This causes modern retail, apart from being a place to shop, also a place of refreshment for some people, and attracts visitors. The retail industry which is growing rapidly these days is a result of the increasing variety of products that are packaged and arranged in a more attractive manner, and also the consumer's need for goods has increased both in quality and quantity. This opportunity is captured by foreign investors who are aggressively building retail networks in big cities in Indonesia. The rapid development of modern retail has also occurred in the city of Surabaya, with the increasing number of large retail companies building their retail networks such as Carrefour, Matahari Department Store, Metro Department Store, and others.

\section{Litterature Review}

\subsection{Theories and Hypotheses}

\subsubsection{Post Transaction Services}

Research by Martin et al. (2015) show that as the number of competitors increases, customers will be offered so many options that cause them to demand services that are more than just a typical shopping experience. Post transaction service is one of the advantages of store services that are usually offered. Therefore, Martin highlighted this additional after service will affect the impression of customers on the store. A positive impression can strengthen the relationship between the customer and the store.

H1: Post transaction service has a significant effect on perceived relationship investment for METRO 


\subsubsection{Direct Mail}

Direct mail is the main element of direct marketing media used by more than one third of direct marketing expenditure in countries (DMA, 2011). Therefore increasing the maximum use of direct mail to improve customer relations can be done through segmentation and targeting, also timing and sorting and by identifying the appropriate number of letters to subscribers. In a study by Merisavo and Raulas (2004), direct mail is defined as a marketing tool to increase the frequency of purchases from customers. In addition, the higher the frequency with which customers respond to messages, there is the potential for a greater increase in customer purchases. Thus, direct mail has a positive effect on perceived relationship investment.

H2: Direct mail has a significant effect on perceived relationship investment for METRO Department Store customers.

\subsubsection{Interpersonal Communication}

In the research of Mavondo and Rodrigo (2001), interpersonal communication is a social bond which is considered as the main antecedent or direct and indirectly important relational output in creating customer perceptions about the store. Relational output refers to customer commitment, trust, and cooperation. Interpersonal communication affects customer to company, customer to employee and customer relationships with customers expressed in the form of customer satisfaction (Rawlins, 1992). Glemler et al., (2001) describe interpersonal communication as the key to a strong store-customer relationship. By creating intimacy between the customer and the salesperson, developing a personal connection through the services displayed by the salesperson. This effort will generate a sense of trust in the store's quality and integrity.

H3: Interpersonal communication has a significant effect on perceived relationship investment for METRO Department Store customers.

\subsubsection{Merchandise}

In a study conducted by Walsh et al. (2011) there is an impact of merchandise on perceived relationship investment which is expressed through customer satisfaction and loyalty. Customer consideration is placed on the value of an item in terms of price and quality (Baker, Parasuraman, Grewal, \& Voss, 2002) where the customer decides whether it is valuable enough to purchase the merchandise itself. In Lee's (1998) study of gasoline quality (merchandise quality) towards gas station loyalty (store loyalty), he explained that the quality of merchandise not only creates customer satisfaction, but contributes to the development of customer loyalty relationships.

H4: Merchandise has a significant effect on perceived relationship investment for METRO Department Store customers.

\subsubsection{Preferentrial Treatment}

Preferential care is designed for the shop's own regular customers, mostly defined as members. Save the usual loyalty programs created as their own in keeping in touch with "members". Yi and Jeon (2003) defined the concept of customer loyalty as they involve the customer loyalty program and brand (company) loyalty program. In addition, the customer loyalty program is described as a positive attitude towards the benefits of the loyalty program. Preferential treatment will build long-term relationships with customers due to store relationships by offering additional benefits to some customers (Hennig-Thurau, Gwinner, \& Gremler, 2002).

H5: Preferential treatment has a significant effect on the perceived relationship investment of METRO Department Store customers. 


\subsubsection{Store Atmosphere}

In a study conducted by Spena et al., (2012), it is stated that the interaction between customers and store atmosphere creates a psychological impact on customer experience and perceived relationship investment, which is referred to as the relationship construction between customers and stores. Another study was also conducted by Levy and Weitz (2012) which explained that store atmosphere, which means how to communicate messages through lighting, music, aroma, decoration and layout, can stimulate customer perceptions through responses and purchases based on emotional behavior. Ismail (2011) states that store atmosphere, service, service quality, and price significantly affect perceived relationship investment. The perceived store atmosphere greatly affects the relationship between customers and stores, therefore increasing the store atmosphere will significantly affect the perceived relationship investment.

H6: Store atmosphere has a significant effect on perceived relationship investment in METRO

Department Store customers

\subsubsection{Perceived Relationship Investment}

Investing time, effort, and resources in building relationships to generate feedback from consumers (Blau, 1964). The thing that is expected to return from customers is a positive perception of perceived relationship investment. Added, Sahin et al. (2016) believe that communication efforts in building relationships affect relational construction by having a positive relationship quality between perceived relationship investment and perceived relationship quality. Research conducted by Kang and Ridgway (1996) explains that perceived relationship investment creates an indirect psychological impact on customers where customers are required to give back their investment in the relationship. Added, Sahin et al. (2013) suggest that relationship-building efforts help assess relationships and develop subsequent behaviors.

H7: Perceived relationship investment has a significant effect on perceived relationship quality for METRO Department Store customers

\subsubsection{Perceived Relationship Quality}

According to Sanchez-Franco et al., (2009), perceived relationship quality combined with the intention of customer behavior to commit to produce attitudinal loyalty. Because the quality of the relationship represents the interaction between the customer and the store. Research also conducted by Huntley (2006) found that there was a direct impact on the willingness to provide recommendations to others based on perceived relationship quality. Behavior that is shown in having commitment and providing recommendations is defined as attitudinal loyalty. Perceived relationship quality is believed to be a combination of three primary dimensions: trust with stores, satisfaction with stores, and commitment to sustainable relationships (Dorsch, Swanson, \& Kelley, 1998).

H8: Perceived relationship quality has a significant effect on attitudinal loyalty to METRO Department Store customers.

\subsection{Research Model}




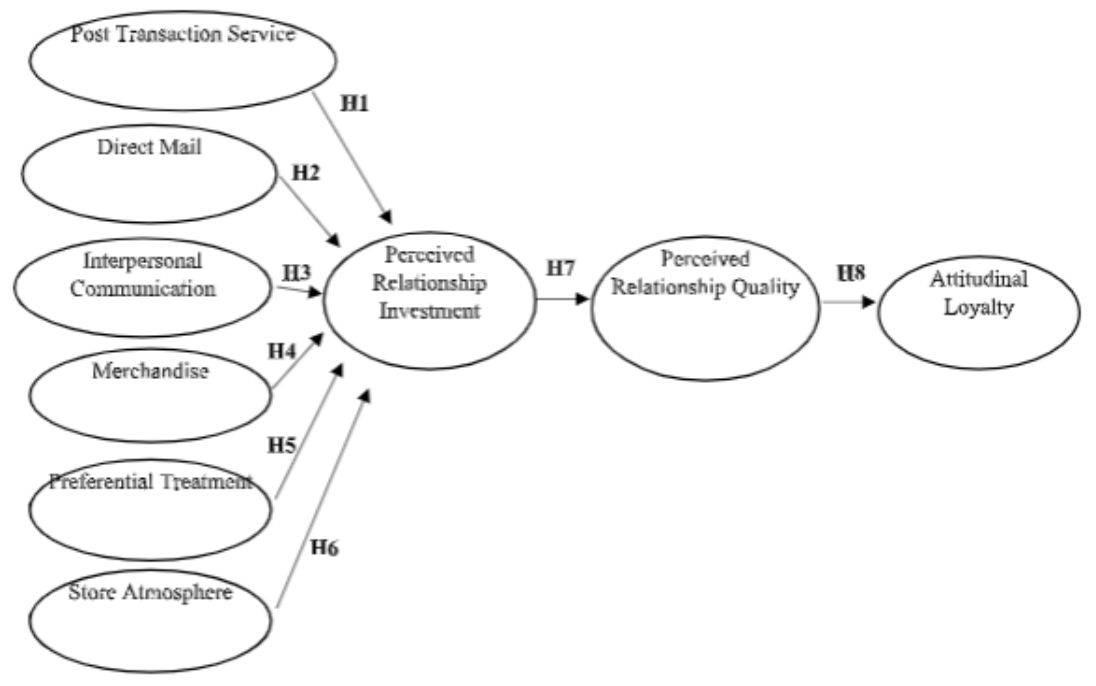

Figure 2.1: The Framework of Research Model

\section{Research Methods}

This research is a causal research, because it is used to develop a previous research model to test the research hypotheses that are determined based on literature review to answer the problems identified in the previous chapter. The research method used in this research is quantitative method, where this method is a scientific approach to managerial and economic decision making. The quantitative method is used because the results of the analysis can be obtained accurately when used according to the rules, can measure the interaction of the relationship between two / more variables and can simplify the reality of complex and complicated problems in a model (Syamrilaode, 2011). This research uses primary data and secondary data. Primary data is data obtained directly from respondents' answers, direct observation of events and objects (Sekaran, 2003), and is used to specifically address research problems (Istijanto in Sunyoto, 2011). The primary data sought were characteristic data regarding attitudinal loyalty to METRO Department Store customers in Surabaya. The second part contains questionnaire statements regarding the effect of post-transaction service, direct mail, interpersonal communication, merchandise, preferential treatment, store atmosphere, on attitudinal loyalty through perceived relationship investment, and perceived relationship quality on METRO Department Store customers in Surabaya. Secondary data is data that is not collected by researchers themselves. Secondary data in this study were obtained by the literature study method, namely data obtained from the literature related to the main problem of this study. Population is a generalization area consisting of certain qualities and characteristics that the researcher determines to study and draw conclusions (Sugiyono in Sarwono, 2010). From this understanding, it can be understood that the population is an area that is determined to be researched by studying and drawing conclusions from the research results. In this case, the population used is customers who make purchases at METRO Department Stores in Surabaya. Judging from the number, the population to be used in this study is included in the population category with an unknown number, namely a population consisting of elements that are difficult to find boundaries. The population used is METRO Department Store customers in Surabaya. The sampling method used in this research is non-probability sampling. This study uses a questionnaire as the main tool in data collection. In this study, researchers will use a 
snowball sampling technique, where the researcher selecting respondents who will help researchers to distribute and fill out questionnaires. The application of the snowball sampling technique in this study was carried out by distributing questionnaires to be distributed to METRO Department Store customers in Surabaya who had purchased at the selected store as the sample. The area used as a place for distributing questionnaires is the city of Surabaya, so that the selected respondents are in accordance with what is expected.

\section{Results and Discussion}

\subsection{Hypotheses Testing}

Table 4.1: Multiple Regression Effects of Post Transaction Sercice, Direct Mail, Iinterpersonal Communication, Merchandise, Preferential Treatment, Store Atmosphere toward Perceived Relationship Investment.

\begin{tabular}{|c|c|c|c|c|c|c|}
\hline Model/ Variable & $\mathrm{R}$ & $\operatorname{Adj} R^{2}$ & $\mathrm{~F}_{\text {sig }}$ & $\begin{array}{c}\text { Standardized } \\
\text { Coefficients } \\
\text { Beta }\end{array}$ & $\mathrm{t}_{\text {sig }}$ & Hypotheses \\
\hline $\begin{array}{l}\text { Post Transaction Sercice, Direct Mail, } \\
\text { Iinterpersonal Communication, } \\
\text { Merchandise, Preferential Treatment, } \\
\text { Store Atmosphere * Perceived } \\
\text { Relationship Investment }\end{array}$ & 0,943 & 0.884 & 0,000 & & & \\
\hline Post Transaction Service & & & & 0.120 & $\begin{array}{c}0.00 \\
5\end{array}$ & Accepted \\
\hline Direct Mail & & & & 0.115 & $\begin{array}{c}0.00 \\
2\end{array}$ & Accepted \\
\hline Interpersonal Communication & & & & 0.138 & $\begin{array}{c}0.00 \\
3\end{array}$ & Accepted \\
\hline Merchandise & & & & 0.497 & $\begin{array}{c}0.04 \\
2 \\
\end{array}$ & Accepted \\
\hline Preferential Treatment & & & & 0.104 & $\begin{array}{c}0.00 \\
1\end{array}$ & Accepted \\
\hline Store Atmosphere & & & & 0.164 & $\begin{array}{c}0.00 \\
0\end{array}$ & Accepted \\
\hline
\end{tabular}

Table 4.2: Simple Regression Effects of Perceived Relationship Investment toward Perceived Relationship Quality

\begin{tabular}{lllllll}
\hline \multicolumn{1}{c}{ Model/ Variable } & $\mathrm{R}$ & Adj R $^{2}$ & $\mathrm{~F}_{\text {sig }}$ & $\begin{array}{c}\text { Standardized } \\
\text { Coefficients } \\
\text { Beta }\end{array}$ & $\mathrm{t}_{\text {sig }}$ & Hypotheses \\
\hline $\begin{array}{l}\text { Perceived Relationship Investment } \\
* \text { Perceived Relationship Quality }\end{array}$ & 0,658 & 0,434 & 0,000 & & & \\
\hline Perceived Relationship Investment & & & & 0.658 & 0,000 & Accepted \\
\hline
\end{tabular}


Table 4.3: Simple Regression Effects of Perceived Relationship Quality toward Attitudinal Loyalty

\begin{tabular}{lcccccc}
\hline \multicolumn{1}{c}{ Model/ Variable } & $\mathrm{R}$ & $\operatorname{Adj~R}^{2}$ & $\mathrm{~F}_{\text {sig }}$ & $\begin{array}{c}\text { Standardized } \\
\text { Coefficients } \\
\text { Beta }\end{array}$ & tsig & Hypotheses \\
\hline $\begin{array}{l}\text { Perceived Relationship Quality } \\
\text { Attitudinal Loyalty }\end{array}$ & 0,505 & 0,255 & 0,000 & & & \\
\hline Perceived Relationship Quality & & & & 0.505 & 0,000 & Accepted \\
\hline
\end{tabular}

\subsection{Discussion}

\subsubsection{The effect of Post Transaction Service toward Perceived Relationship Investment}

Based on SPSS analysis result, estimation parameters between the Post Transaction Service Toward Perceived Relationship Investment, Direct Mail Toward Perceived Relationship Investment, Interpersonal Communication Toward Perceived Relationship Investment, Merchandise Toward Perceived Relationship Investment, Preferential Treatment Toward Perceived Relationship Investment, Store Atmosphere Toward Perceived Relationship Investment, Store Atmosphere Toward Perceived Relationship Investment, Perceived Relationship Investment Toward Perceived Relationship Quality, and Perceived Relationship

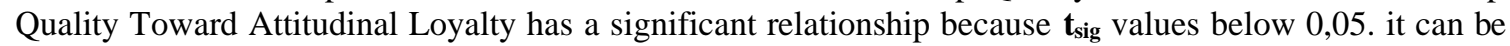
said that hypothesis $\mathrm{H} 1, \mathrm{H} 2, \mathrm{H} 3, \mathrm{H} 4, \mathrm{H} 5, \mathrm{H} 6, \mathrm{H} 7$, and $\mathrm{H} 8$ were accepted. The results exhibited that all the hypothesized variables played important roles in predicting Attitudinal Loyalty to METRO Department Store on Surabaya. The findings of this study provide several important implications for Attitudinal Loyalty research and practice, especially in retail industry in the future.

\subsubsection{The effect of Post Transaction Service toward Perceived Relationship Investment}

The estimation parameters between Post Transaction Service and Perceived Relationship Investment show significant results in a positive direction with a value of $t$ test where the significance is 0.005 (below 0.05 ) which indicates that this hypothesis is accepted. Post Transaction Service is one of the more extra shop services that are usually offered to customers. The added impression after providing this service affects the customer's impression of the shop. A positive impression can strengthen the customer relationship with the shop. The result of this research is that METRO Department Store in Surabaya improves post-transaction services by making product return procedures easier with appropriate product exchange services, and increasing the knowledge of sales staff about product exchange procedures through training or training.

\subsubsection{The effect of Direct Mail toward Perceived Relationship Investment}

The estimation parameters between Direct Mail and Perceived Relationship Investment show significant results in a positive direction with a value of $t$ test where the significance is 0.002 (below 0.05 ) which indicates that this hypothesis is accepted. Direct Mail as a marketing tool to increase customer purchasing frequency. Because the higher the frequency of customers responding to messages sent, the potential for increasing the frequency of customer purchases will be even greater. Thus, Direct Mail is consistently used to increase Customer Relationship Investment. This study suggests that METRO Department Store in Surabaya improves Direct Mail by regularly sending product catalogs, updates, and event brochures by email in a more creative and attractive way for METRO Department Store customers in Surabaya.

\subsubsection{The effect of Interpersonal Communication toward Perceived Relationship Investment}

The estimation parameters between Interpersonal Communication and Perceived Relationship Investment show significant results in a positive direction with a value of t-test where if Sig. $\leq 0.05$, the hypothesis is accepted. Sig. Interpersonal Communication Value 0.003, standard value 0.05, hypothesis is accepted. Interpersonal Communication as the key to a strong Perceived Relationship Investment. By creating intimacy between customers and salespeople, personal relationships can be developed through the attention shown by the seller. These efforts will generate trust from customers in the store. All department stores in 
Surabaya use the same benchmark method, namely the Service Quality Index (SQI) where interpersonal communication is included as one of the assessments. Thus, a department store serving the same market segment as METRO Department Store, the upper middle class segment such as Sogo has the same interpersonal communication standards in handling customers. In it concerns the ways and skills of salespeople in providing services to customers. For example, how salespeople communicate or explain product knowledge to customers in a creative way, and explore what customers need so that customers will be interested in buying at METRO Department Store in Surabaya.

\subsubsection{The effect of Merchandise toward Perceived Relationship Investment}

The estimation parameters between Merchandise and Perceived Relationship Investment show significant results in a positive direction with a value of $\mathrm{t}$-test where if Sig. $\leq 0.05$, the hypothesis is accepted. Sig. Interpersonal Communication Value 0.000, standard value 0.05, hypothesis is accepted. There is an influence of Merchandise on building Perceived Relationship Investment which is expressed through customer satisfaction and loyalty. Store-sold products are considered as the most important antecedents that influence customer-store relationships to generate customer loyalty.

\subsubsection{The effect of Preferential Treatment toward Perceived Relationship Investment}

The estimation parameters between Preferential Treatment and Perceived Relationship Investment show significant results in a positive direction with a value of t test where the significance is 0.042 (below 0.05 ) which indicates that this hypothesis is accepted. The focus of preferential treatment builds a long-term relationship between the customer and the store by offering additional benefits to multiple customers. This research results that METRO Department Store in Surabaya improves their preferential treatment by increasing extra services for regular customers (members) by providing more special promotions, then METRO Department Store in Surabaya can improve its services in providing information to regular customers (members).

\subsubsection{The effect of Store Atmosphere toward Perceived Relationship Investment}

The estimation parameters between Store Atmosphere and Perceived Relationship Investment show significant results in a positive direction with a value of t-test where the significance is 0.042 (below 0.05 ) which indicates that this hypothesis is accepted. Where the shopping experience at the store greatly affects the relationship between customers and the store, therefore increasing the shop atmosphere will significantly affect Perceived Relationship Investment. Spena et al. (2012) stated that the interaction between the customer and the shop atmosphere has a psychological impact on the customer experience and triggers a shared value creation process, which is called the relationship construct. This research shows that METRO Department Store in Surabaya can improve the shop atmosphere by creating a more attractive appearance and tenant decoration so that it can attract targeted customers, METRO can also improve customer space management and tenant placement arrangement based on product category.

\subsubsection{The effect of Perceived Relationship Investment toward Perceived Relationship Quality}

The estimation parameters between Perceived Relationship Investment and Perceived Relationship Quality show significant results in a positive direction with a value of t-test where the significance is 0.000 (below 0.05) which indicates that this hypothesis is accepted. Communication efforts in building relationships have an impact on the relational construct by having a positive relationship quality. This study results that METRO Department Store in Surabaya increases Perceived Relationship Investment by offering more promotional programs, additional services, and events related to building relationships with regular customers (members).

\subsubsection{The effect of Perceived Relationship Quality toward Attitudinal Loyalty}

The estimation parameters between Perceived Relationship Quality and Attitudinal Loyalty show significant results in a positive direction with a value of t test where the significance is 0.000 (below 0.05) which indicates that this hypothesis is accepted. direct influence on the willingness to provide recommendations to 

recommendations is interpreted as an attitude of loyalty. This research suggests that METRO Department Store in Surabaya improves the perception of relationship quality by ensuring that customers are happy with the shop and customer relationship, customers develop a sense of trust, and customers have trusted METRO Department Store in Surabaya as the right place to shop.

\section{Conclusion}

This study provides evidence that the Post Transaction Service affected Perceived Relationship Investment, Direct Mail affected Perceived Relationship Investment, Interpersonal Communication affected Perceived Relationship Investment, Merchandise affected Perceived Relationship Investment, Preferential Treatment affected Perceived Relationship Investment, Store Atmosphere affected Perceived Relationship Investment, Store Atmosphere affected Perceived Relationship Investment, Perceived Relationship Investment affected Perceived Relationship Quality, and Perceived Relationship Quality affected Attitudinal Loyalty.

Table 5.1: Managerial Implications

Current Research Managerial Implications

Merchandise significantly affected Perceived Relationship Investment
1. Following market trends, for example expanded product variations to keep up with the latest trends such as hype beast products.

2. Creating innovation by understanding current trends, such as creating new product categories on environmental care and eco products.

3. Strict and regular inventory checks to ensure product quality.

Store Atmosphere significantly affected Perceived Relationship Investment

1. Create new innovations in decoration and appearance and arrangement of tenants.

2. Set the store arrangement with a new system, which can add visual appeal to customers.

3. Create a dedicated space for product sales during a major sale. Renting a hall at a shopping mall can be an option to increase space in the shop.

Interpersonal Communication significantly affected Perceived Relationship Investment

1. Ongoing training to remind staff of the vision and mission and values of METRO's customer service department.

2. Skills development to improve communication skills, such as presentation skills to make them appear more convincing and ethical.

3. Creating a platform for customer reviews or assessments related to services at METRO Department Store in Surabaya.

Post Transaction Service significantly affected Perceived Relationship Investment
1. Create an integrated Post Transaction Service feature in the METRO membership mobile application, where customers submit posttransaction service requests, such as product exchange services or product returns.

2. Improved post-transaction service SOPs by shortening waiting times.

3. Providing regular provision and training 
Direct Mail significantly affected Perceived Relationship Investment

1. Improve email content, such as adding tips and tricks in styling.

2. Create an attractive e-mail display to attract customers to read, such as METRO can write interesting headlines.

3. Increase e-mail as a marketing tool by creating an exclusive impression, such as special invitations for events held for members.

Preferential Treatment significantly affected Perceived Relationship Investment
1. Create extra sales promotion programs, such as additional special discounts for customers who have members.

2. Creating extra programs and services that give a special feeling to customers who have members, such as additional sales promotions.

3. When transacting with METRO employees, employees will explain more information about the benefits of being a member, promotions, events that may be attended by members, which are not accepted by non-member customers.

Perceived Relationship Investment
significantly affected Perceived Relationship
Quality

1. Offering special extra services dedicated to those who have members.

2. Provide reward points for METRO Department Store members for every purchase, and give extra cashback of $30 \%$ (max. Cashback of IDR $150,000)$ for new members who have been registered so that they can attract more customers to join the loyalty membership.

3. Giving priority invitations to METRO Department Store members during a premium brand launch event.

Perceived Relationship Quality significantly

1. Give gifts to customers who shop more than minimum spend, to increase the enthusiasm for shopping at METRO Department Store Surabaya.

2. Develop a training program for METRO employees to provide reliable and reliable information to customers.

3. Hold seasonal promotions during special events held every year, such as Christmas, Chinese New Year, Idul Fitri where METRO also sells special products.

\subsection{Recommendation}

Looking at the results of existing research where there are still many limitations to the research conducted by the author, the recommendations that can be submitted by the author are as follows:

- Seeing the limitations regarding the research object that only takes respondents, namely METRO Department Store customers in Surabaya, it is hoped that the next research using the same or modified model can be applied to different objects to get more general results on the factors that 
- Further research is expected to complement the existing variables in this research so that it can further enhance the understanding of the factors that affect Attitudinal Loyalty. for example, further research adds the variable word of mouth and others.

- Further research can be developed by linking the factors that influence Attitudinal Loyalty based on income level, age, and gender. Future research could also expand the scope of respondents to be researched, or carry out their research in a different area from the current research. So that the further research carried out provides a broad picture of Attitudinal Loyalty.

\section{References}

Anderson, J. and Gerbing, D. (1988), "Structural equation modeling in practice: a review and recommended two-step approach", Psychological Bulletin, Vol. 103 No. 3, pp. 411-23.

Angriawan, F. (2011). Pengaruh Brand Image, Service Quality, dan Perceived Value Terhadap Brand Loyalty Kartu Prabayar GSM PT. Indosat Di Semarang. Skripsi. Universitas Dipenogoro Semarang.

Anselmsson, J. (2006), "Sources of customer satisfaction with shopping malls: a comparative study of different customer segments", The International Review of Retail, Distribution and Consumer Research, Vol. 16 No. 1, pp. 115-38.

Ariningsih, E. 2009. Pengaruh Perceived Value pada Loyalitas Konsumen yang dimediasi oleh Kepuasan Konsumen dan dimoderatori oleh Gender. Jurnal Manajemen. Universitas Muhammadiyah Purworejo.

Bagozzi, R.P. (1995), "Reflections on relationship marketing in consumer markets", Journal of the Academy of Marketing Science, Vol. 23 No. 3, pp. 272-7.

Baker, J., Parasuraman, A., Grewal, D., \&amp; Voss, G. B. (2002). The influence of multiple store environment cues on perceived merchandise value and patronage intensions. Journal of Marketing.

Banat, A., \&amp; Wandebori, H. (2012). Store Design and Store Atmosphere Effect on Custmer Sales per Visit. 2nd International Conference on Business. Economics, Management and Behavioral Sciences. Bali (Indonesia).

Barich, H. and Srinivasan, V. (1993), "Prioritizing marketing image goals under resource constraints", Sloan Management Review, Vol. 34 No. 4, pp. 69-76.

Bastian, Z. 2013. Strategi Manajemen Dalam Membangun Merek yang Kuat. Jurnal Marketing. ASM Ariyanti. Brady, D. (2000, October 23). Business Week: Why Service Stinks. Diambil kembali dari Bloomberg: https://www.bloomberg.com/news/articles/2000- 10-22/why-service-stinks

Business Wires. (2017, October 15). Retail Market in Indonesia to Witness Rapid Growth Through 2021 | Technavio. Diambil kembali dari Global Indonesian Voices: http://www.globalindonesianvoices.com/31357/retail- market-in-indonesia-to-witness-rapidgrowth-through-2021-technavio/

Chaudhuri, A., \&amp; Holbrook, M. B. (2001). The chain of effects from brandtrust and brand affect to brand performance: The role of brand loyalty. Journal of Marketing, 81-93. 

di Indonesia Edisi Ke dua. Salemba empat. Bandung.

Costabile, M., Raimondo, M.A. \& Miceli, G. 2002. A Dynamic Model of Customer Loyalty. Proceedings of the 31st Annual Conference of the European Marketing Academy, 28-31 May, Braga.

Crosby, L. A., Evans, K. R., \&amp; Cowles, D. (1990). Relationship quality in service selling: An interpersonal influence perspective. Journal of Marketing.

De Wulf, K., \&amp; Odekerken-Schröder, G. \&amp;. (2001). Investment in consumer relationship: A cross $=$ country and cross $=$ industry exploration. Journal of Marketing.

Dekimpe, M. G., Steenkamp, J. E., \&amp; Vanden, A. P. (1997). Decline and Variability in bran loyalty. International Journal of Research in Marketing, 405-420.

Deutsch, M. (2011). Interdependece and psychological orientation,. Dalam Conflict, Interdependence, and Justice. New York: Springer.

Dirgantara, D. B., \& Devie, E. (2019). The influence of price, perceived quality, and brand image on customer post purchase behaviour of frestea at pt coca cola amatil indonesia semarang. Jobs (Jurnal Of Business Studies), 4(2), 105-118. Dwyer, F. R., \&amp; Oh, S. (1987). Output Sector Munificence Effects on the Internal Political Economy of Marketing Channe;s. Journal of Marketing Research.

Dwyer, F. R., Schurr, P. H., \&amp; Oh, S. (1987). Developing Buyer-Seller Relationships. Journal of Marketing.

Etikan, I., \&amp; Bala, K. (2017). Sampling and Sampling Methods. Biometrics \& Biostatistica International Journal. Focus Economics. (2019, January 22). Indonesia Economic Outlook. Diambil kembali dari Focus Economics: https://www.focus-economics.com/countries/indonesia

Françoise, S., \&amp; Andrews, L. (2015). A relational approach to direct mail consumption. European Journal of Marketing.

Ghozali (2004) Consumer Demographics, Store Attributes and Retail Format Choice in The US Grocery Market. Vol. 34,

Gibson, J., Ivancevich, J. M., Jr., J. H., \&amp; Konopaske, R. (2012). Organizational: Behavior. Structur, Proceses. New York: Mc Graw-Hill.

Gilly, M. C. (1979). Complaining consumer: Their satisfaction with organization responses

Gremler, D. D., Gwinner, K. P., \&amp; Brown, S. W. (2001). Generating positive word-of-mouth communication through customer-employee relationships. Service Industry Management.

Gummesson, E. (1987). Quality: The Ericsson Approach. Stockholm: Ericsson.

Gwinner, K. P., Gremler, D. D., \&amp; Bitner, M. J. (1998). Relational benefits in services industries: The customer\&\#39;s perspective. Journal of the Academy of Marketing Science.

Hair, J., Black, W., Babin, B., Anderson, R., \&amp; Tatham. (2006). Multivariate data analysis (6th ed.). Uppersaddle River, New Jersey: Pearson Prentice Hall.

Harker, M. J., \&amp; Egan, J. (2010). The Past, Present and Future of Relationship Marketing. Marketing 
Hart, C. W., \&amp; Johnson, M. D. (1999). Growing the trust relationship. Marketing Management. Haryanto, Bambang. (2014). Pengaruh Kualitas Produk dan Suasana Toko Terhadap Loyalitas

Hussain, R., \&amp; Ali, M. (2015). Effect of Store Atmosphere on Consumer Purchase Intention. International Journal of Marketing Studies.

Hussain, R., \&amp; Ali, M. (2015). Effect of Store Atmosphere on Consumer Purchase Intention. International Journal of Marketing Studies.

Kotler, P. (1973). Atmospherics as a marketing tool. Journal of retailing.

Kotler, P. (2003). Marketing Management. New Jerse: Prentice Hall.

Kotler, P., \&amp; Armstrong, G. (2001). Principles of marketing. New Delhi: Prentice-Hall of India Private Limited.

Kotler, P., \&amp; Keller, K. L. (2005). Marketing management. New Delhi: Prentice-Hall of India Private Limited.

Kotler, P., \&amp; Keller, K. L. (2012). Marketing Management. New Jersey: Pearson Education, Inc.

Kotler, Philip dan Keller, Kevin Lanne. (2014). Marketing Management $14^{\text {th }}$ Edition Practice Hall. Pearson Kotler, Philip, Bowen, Jhon T., Makens, James C. (2010). Marketing for Hospitality and Tourism. New Jersey : Pearson Kumar, A., \&amp; Anjaly, B. (2017). How to measure post-purchase customer exerience in online retailing? A scale development study. International Journal of Retail \&amp; Distribution Management.

Kumar, N., Scheer, L. K., \&amp; Steenkampt, J.-B. E. (1995). The Effets of Supplier Fairness on Vulnerable Resellers. Journal of Marketing Research.

Kurniawan, D. (2013). Pengaruh promosi dan store atmosphere terhadap impulse buying dengan shopping emotion sebagai variabel intervening studi kasus di Matahari department store cabang supermall Surabaya. Jurnal Strategi Pemasaran, 1(2), 1-8.

Lacey, R., Suh, J., \&amp; Morgan, R. (2007). Differential affects of preferential treatment levels on relational outcomes. Journal of Service Research.

Lacey, R., Suh, J., \&amp; Morgan, R. M. (2007). Differential Effects of Preferential Treatment Levels on Relational Outcomes. Service Research.

Lee, D. (1998). The effects of product quality and service quality on consumer satisfactionn and loyalty - A study of gas station, master thesis. Taiwan: National Cheng Chi University.

Lovelock, Christopher et.al. (2012). Essentials of ServiceMarketing. End Edition. Singapore: Prentice Hall

Mat, A., Ali, A. M., Salleh, M. Z. M., \& Kori, N. L. (2014). Post-Purchase Behavior: Consume Complaint Behavior. PAPER TITLE AUTHORS PAGE NUMBER 1 The Tensile Strength Analysis of, 123.

Nguyen, T.T.M., Tho D.N., \& Nigel J.B. (2007). Hedonic Shopping Motivation and Shoppers Loyalty in transitional markets. Asia Pacific Journal Marketing and Logistics. Vol.19 
of Product \& Brand Management, Vol. 6 No. 6, pp. 373-87. 343

Pritchard, M. P., Havitz, M. E., \&amp; Howard, D. R. (1999). Analyzing the Commitment-Loyalty Link in Service Contexts. Journal of the Academy of Marketing Science.

Pritchard, M.P., Howard, D.A. and Havitz, M.E. (1992), "Loyalty measurement: a critical examination and theoretical extension", Management Science, Vol. 38 No. 2, pp. 155-64. Priyanto, D. (2010). Paham Analisa Statistik dengan SPSS. Yogyakarta: MediaKom.

Rawlins, W. K. (1992). Friendship Matters. New York: Aldline de Gruyter, Hawthrone.

Reibstein, D. (2002). What attracts customers to online stores, and what keeps them coming back? Journal of the Academy of Marketing Science.

Reichheld, F.F. (2003), “The one number you need to grow”, Harvard Business Review, Vol. 81 No. 12, pp. 46-54.

Robbins, S. P., \&amp; Judge, T. A. (2012). Organizational Behavior. New Jersey: Pearson Education.

Roberts, K., Varki, S. and Brodie, R. (2003), "Measuring the quality of relationships in consumer services: an empirical study", European Journal of Marketing, Vol. 37 Nos 1/2, pp. 169-96.

Rundle-Thiele, S. (2005). Exploring loyal qualities: assesing survey-based loyaltymeasures. Journal of Service Marketing, 492-500. Setiadi, Nugroho J. (2003). Perilaku Konsumen: Konsep dan Implikasi Untuk Strategi dan Penelitian Pemasaran. Jakarta: Prenada Media

Severin, V., Louviere, J.J. and Finn, A. (2001), “The stability of retail shopping choices over time and across countries", Journal of Retailing, Vol. 77 No. 2, pp. 185-202.

Shankar, V., Smith, A.K. and Rangaswamy, A. (2003), "Customer satisfaction and loyalty in online and offline environments", International Journal of Research in Marketing, Vol. 20 No. 2, pp. 153-75.

Thang, D. and Tan, B. (2003), "Linking consumer perception to preference of retail stores: an empirical assesment of the multi-attributes of store image", Journal of Retailing and Consumer Services, Vol. 10 No. 4, pp. 193-200.

Utami, Christina Whidya. 2010. Manajemen ritel ,edisi kedua .Jakarta : Salemba empat.

Wang, Chiu Han dan Ha, Sejin. (2011). Store attributes Influencing Relatiomships Marketing : A Study of Department Stores. Journal of Fashion Marketing and Management. Vol. 15 No.3,

Wong, Y.H., Hung, H. and Chow, W.K. (2007), "Mediating effects of relationship quality on customer relationships: an empirical study in Hong Kong”, Marketing Intelligence \& Planning, Vol. 25 No. 6, pp. 58 
X1: Appropriate product exchange services

$\mathrm{X} 2$ : Product return procedures that are not burdensome to the customer

X3: Employees have good knowledge of product exchange service procedures

X4: Send product catalog e-mails periodically

$\mathrm{X} 5$ : Inform the latest promotion updates via email

X6: Distributing brochures containing interesting events via email Interpersonal Communication Indicators

X7: Employees friendly help when shopping at the store

$\mathrm{X} 8$ : Store employees provide the best service

X9: Employees take time to explain the product

Preferential Treatment Indicators

X10: Shop cashiers provide more service for member customers

X11: Provide various additional promotions for regular customers

$\mathrm{X} 12$ : Provide more detailed product information to regular customers Store Atmosphere Indicators

X13: Interesting tenant appearance

$\mathrm{X} 14$ : Interesting shop decoration

X15: The shop has a large space

$\mathrm{X} 16$ : Easy shop setup to find products

X17: Can find all necessities in the shop

$\mathrm{X} 18$ : The product offered is attractive

$\mathrm{X} 19$ : Product quality is in line with expectations

X20: The shop offers various categories of quality products Perceived Relationship Investment Indicators

X21: Has a variety of promotional programs to improve good relations with regular customers

$\mathrm{X} 22$ : Has a variety of additional services to improve good relations with regular customers

X23: Having various events to improve good relations with regular customers Perceived Relationship Quality Indicators

X24: Feeling happy with customer relationships at the store

X25: Good relationship with customer relationship makes customers trust

$\mathrm{X} 26$ : Trust the shop as a place to shop

$$
\text { Attitudinal Loyalty Indicators }
$$

X27: Recommending the shop to friends and relatives

$\mathrm{X} 28$ : Choose a shop for shopping over others

$\mathrm{X} 29$ : The shop is the main shopping place 